\title{
1 \\ Unequal Lives in the Western Pacific
}

Nicholas Bainton and Debra McDougall

In October 2018, as Papua New Guinea (PNG) prepared to host the Asia-Pacific Economic Cooperation (APEC) meeting in Port Moresby, journalists reported on stark disparities that were drawing the ire of the nation. News headlines announced that the national government had just splurged on 40 Maseratis for APEC leaders (Beldi, 2018). Photos showed cargo planes unloading carefully sheathed luxury cars, each one valued at more than 100 times PNG's per capita gross domestic product (GDP). Government officials claimed these were needed to transport visiting dignitaries in 'comfort and safety' (if not style). In a nation where most roads are in disrepair and four-wheel-drives are a transport necessity, rather than a luxury, many people were outraged by the purchase. Meanwhile, in Enga Province, hundreds of kilometres from the APEC hype, a young child died of polio, more than 20 years after the last polio death and 18 years after the country was declared free of polio. His death was not an isolated case; approximately 140 other Papuan New Guineans were reportedly suffering from severe polio symptoms (Murray-Atfield, 2018). The outbreak of this once-vanquished disease, contrasted with such ostentatious displays of wealth in the nation's capital, was a vivid manifestation of a failing health system, entrenched inequalities and perverse political priorities. 
The following year, the small atoll nation of Tuvalu hosted the Pacific Islands Forum. Regional inequalities once again reached the headlines. This time, attention focused on the threat posed by climate change to people in the Pacific and Australia's refusal to acknowledge a climate crisis and take meaningful action on this issue. Regional leaders could barely disguise their anger at Australia's failure to recognise its moral responsibilities to its 'Pacific family' (Kabutaulaka \& Teaiwa, 2019; Regenvanu, 2019). Back in Australia, the deputy prime minister blithely dismissed these concerns, stating that Pacific Islanders 'will continue to survive ... because many of their workers come here and pick our fruit' (McCormack, 2019). Referring to the Seasonal Worker Program, his comments evoked a colonial arrogance that highlighted the deep inequalities structuring relations between Australia and the Pacific. Parallels were quickly drawn with the history of indentured labour, where Pacific Islanders were 'blackbirded' throughout the nineteenth century to work in Australian cane fields (Banivanua-Mar, 2006; Stead \& Altman, 2019). As this volume goes to press, the COVID-19 pandemic is also highlighting dramatic differences in life chances across and within national borders. The medical systems of the Western Pacific are illequipped to deal with existing health challenges, let alone this new virus (Aqarau, 2020; Wood, 2020). Aside from the risks of the virus itself, the pandemic threatens to trigger fear and social unrest, including antisorcery violence (Cox \& Phillips, 2015; Hukula, Forsyth \& Gibbs, 2020). And in Australia, temporary Pacific workers are not being provided with the same substantial social support that other workers are now receiving from the government (Stead, 2020).

These events reflect the radically divergent effects of globalised capitalism on the lives of people who call the Western Pacific home. Wherever we look, the powerful are siphoning life-giving resources away from the poor with impunity - sometimes with their support at the ballot box. Lavish consumption by the powerful few is combined with declining living standards for the majority. This scenario is unfolding across the world; however, as the chapters in this volume show, the abomination of growing inequality takes a distinctive form in the western corner of the Pacific. The region came under colonial rule from the late nineteenth century, but indigenous inhabitants were not displaced from their land by settlers in the way that the peoples of Australia, Hawai' $i$ or Aotearoa New Zealand were. The almost-continent-sized island of New Guinea and the large volcanic islands to its east are rich in soil, minerals, water, forests and 
people. Yet this remains the poorest region of the Pacific, with the lowest GDP per capita and the lowest human development index scores (United Nations Development Programme, 2018).

Our focus in this volume is primarily PNG, with a chapter on Solomon Islands and reflections on Vanuatu. These three countries are often identified as part of the geocultural region of 'Melanesia' - a term that emerged from the racialised sciences of nineteenth-century Europe and remains important as a marker of sub-regional identity among both independent and colonised states of the Western Pacific (Jolly, 2001; Kabutaulaka, 2015; Lawson, 2013; Thomas, 1989). PNG, Solomon Islands and Vanuatu are all linguistically and culturally diverse nations with small immigrant populations. These features set them apart from Fiji, also identified as 'Melanesian', where discussions of inequality pivot on the racialised tensions between citizens with indigenous and migrant backgrounds (Bryant-Tokalau, 2012; Trnka, 2008). In contrast to West Papua and New Caledonia, PNG, Solomon Islands and Vanuatu are politically independent, no longer subject to racialised colonial rule. Although independence ended some of the most overt forms of racial inequality, the region remains beholden to foreign donors who use their military and economic power to undermine the priorities of Pacific peoples and their visions of the future. Simply put, race remains important in local understandings of inequality. The regions' struggling middle or working classes resent the exponential differences between their own paltry wages and those of handsomely paid (and mostly white) consultants from former colonial powers and other metropolitan nations. Meanwhile, the rising economic and political power of China has led to new and disturbing expressions of anti-Chinese violence.

This volume teases out particular dilemmas of inequality in the Western Pacific. Through close ethnographic inquiry, the authors show that current inequalities cannot be disentangled from deep colonial legacies and neo-colonial discrimination; they argue that contemporary inequalities are multidimensional and multiscale. In the remainder of this introductory chapter, we reflect upon the significance of global inequality, its particularities in the Western Pacific and chart the contribution that anthropologists have made towards understanding one of the most pressing issues of the region and our time. We sketch an intersectional approach to inequality in the Western Pacific (as both an approach and a point of commonality between the chapters) and then provide an overview of the major threads running through the volume. 


\section{A Global Epidemic of Inequality}

As we move further into the twenty-first century, we are witnessing both the global extensification and local intensification of inequality. The statistics are stupendous; over the past three decades, income and wealth inequality have grown exponentially, and the gap between the mega-rich and the rest has grown deeper and wider. ${ }^{1}$ Scholars and public intellectuals, politicians and the public and multilateral institutions like the United Nations (UN) are increasingly concerned with inequality as a powerfully malign feature of contemporary life. Inequality is not only terrible for those at the bottom but also terrible for those at the top, not least of all because it fuels social and political instability (Wilkinson $\&$ Pickett, 2009). This manifests in multiple and mutable ways and is especially so in the Western Pacific.

To be sure, considerable improvements have been observed in global quality of life. In the Global North, the years that followed World War II produced great economic prosperity and optimism, and many governments were committed to some form of wealth distribution, including to former colonies in the Global South. Economic modernisation and development programs provided technical assistance and capital injection to help the global poor 'catch up'. Development aid was deeply tied to Cold War politics. It was also grounded in an ideology of progress within the booming economies of Europe and the United States that promised a path for the future in the poorer countries of the world. In more recent decades, global levels of absolute poverty, illiteracy, child malnutrition and child labour have fallen at some of the fastest rates in human history and life expectancy has increased for many people. The proportion of the global population living in servitude has fallen dramatically, and many people who were formally persecuted due to their gender, race, sexuality or disability now enjoy a wider range of rights and freedoms. Likewise, a smaller proportion of the global population lives under authoritarian, tyrannical or dictatorial regimes and, despite the global rise of authoritarian politics, a larger proportion of people live within some form of moderately accountable democracy.

1 By 2018, the global top 1 per cent of earners had captured twice as much of global growth in income as the poorest bottom 50 per cent of the population (Alvaredo et al., 2018). 
Arguably, however, these measures of rising wellbeing say little about whether people feel that their lives are improving. If globalisation has brought people closer together, this real or virtual proximity has also highlighted the vast differences in standards of living across different classes and countries. Moreover, while gains have occurred in some places, absolute levels of poverty have increased in other places, especially Sub-Saharan Africa (World Bank, 2018). The grim effects of neoliberal political and economic reforms in the 1970s have been profound, often unravelling previous improvements and hard-fought gains made during the so-called era of 'embedded liberalism'. As the World Bank and the International Monetary Fund enforced their structural adjustment programs and other forms of 'shock therapy' (Klein, 2007), the economies of many smaller and poorer nations were crushed in ways that immiserated the lives of their inhabitants, while the economies of many Western nations (and the accounts of specific corporations) prospered at their expense. The global spread of neoliberal policies and projects has undermined the capacity of nation states to buffer the vagaries of market forces and ensure the wellbeing of all their people. The relentless privatisation of public goods and services, the reduction of social assistance programs and the removal of government regulations on big corporations (or the failure to apply these rules consistently) has helped to entrench massive socioeconomic inequalities.

Privatisation has also meant that the contract between labour and capital has been torn apart; workers in this new economy are forced to adapt to the logic of the temporary and insecurity has been normalised under the guise of flexibility. In a world that seems to be developing a contemptuous attitude towards the poor and working classes, the ideal subject is the responsible 'self-managing entrepreneur', who is expected to believe that the path to freedom and wellbeing can be found in greater levels of self-exploitation-or plain hard work. At the same time, reliance upon the extraction of non-renewable resources has unleashed new forms of inequality linked to environmental destruction and forced dislocation, the privatisation and enclosure of common property and modern forms of wage slavery. Old forms of 'primitive accumulation' that transferred labour and raw resources from the colonies to the core through bloody raids and violent seizures have been supplanted by more insidious and enduring forms of 'accumulation by dispossession' that redistribute wealth upwards and across capitalist economies (Harvey, 2005). A sizeable portion of this wealth is now concentrated in the hands of an emerging 
global oligarchy that, according to Thomas Piketty (2014), reflects a global return to 'patrimonial capitalism', which we could summarise as a form of 'accumulation by inheritance'. A proliferation of tax breaks and tax havens have further redefined the geography of accumulation, as dis-embedded and unencumbered capital flows freely between global cities and their once-remote tax haven entrepôts (Shaxson, 2011).

Feelings of abject disconnection and pervasive expressions of resentment have emerged among some low-income populations in the spaces left by the decline in traditional working-class forms of social and political solidarity. Identity- and place-based politics have flourished, as cultural interests trump economic interests and political leaders exploit the fears and aspirations of those who long for the supposed security of times gone by. In some industrialised democracies, these political and economic changes have engendered feelings of anxiety and helplessness, which partly aid in explaining the rise of populist politicians, the revival of older political forms and the re-emergence of paranoid politics and authoritarian responses.

Against this global backdrop, we believe that a focus on inequality is important due to the ways that inequality consistently undermines individual and collective wellbeing. Beyond an inability to enjoy the things that money can buy, the poor of the world are more vulnerable in almost every imaginable way, perhaps most frighteningly by climate change-induced catastrophes and other environmental and viral hazards that the world's wealthy have caused but are able to escape (Jolly, 2019; Robbins, 2017). As we noted at the outset, this asymmetry has become an urgent issue in the Pacific. The consequences of such uneven development are profound, and these processes might be understood as another form of 'slow violence' that is imposed upon disadvantaged groups of people in distant places.

\section{Capitalism(s) and the State in the Western Pacific}

Serious socioeconomic and political inequality has a relatively shallow history in the Western Pacific. In the pre-colonial era, status hierarchies were relatively modest-nowhere did the socio-genealogical distance between chiefs and commoners approach those of the great kingdoms of Tonga or 
Hawai i. Moreover, unlike the islands of eastern Indonesia, Western Pacific societies were not incorporated into ancient Hindu-Buddhist polities or Muslim trading networks. Until the advent of European colonialism in the late nineteenth century, no imperial languages were superimposed, no tributes were exacted, and no overarching power claimed sovereignty over local communities. Political authority was grounded in relationships with ancestors, living kinsfolk and allies. Even where status was inherited genealogically, there was little intergenerational accumulation of material wealth or rights to mobilise labour. Inequalities certainly existedeverywhere, men exercised power over women, and elders exercised power over youth. However, until the last generation or two, there were no classes or castes, no landless peasants and no aristocrats.

The history of contemporary inequality in the Western Pacific begins with colonial expropriation of land, labour and resources in the nineteenth century. The presence of European traders and whalers transformed indigenous social worlds through new infectious diseases, tobacco, trade goods and steel tools. Local leaders with access to Europeans were able to dominate those without such access - the beginning of new kinds of internal inequalities. ${ }^{2}$ Perhaps the most momentous development in the islands of Melanesia was the labour trade. Early recruiters used violence and trickery; later, the need for money and trade goods induced tens of thousands of recruits to sign up with limited awareness of the harsh conditions and high mortality rates they would face on the plantations of Queensland and Fiji (Banivanua-Mar, 2006; Siegel, 1985). In the early twentieth century, Australia's racist immigration legislation ended the Queensland labour trade but indenture continued within the boundaries of newly established colonial administrations. This internal labour mobility helped to consolidate the differentiation between 'haves' and 'have-nots' within the territories that would become Vanuatu, Solomon Islands and PNG.

These emergent inequalities had powerful effects when PNG gained independence from Australia in 1975, Solomon Islands from the United Kingdom in 1978 and Vanuatu from the condominium government of France and the United Kingdom in 1980. Colonial administrations sought to create an indigenous elite, as quickly as possible, to staff government offices and fill other roles that had hitherto been reserved for white men.

2 See, for example, Martha Macintyre (1994) on the importance of colonial relations in the dominance of Trobriand Islanders in the kula exchange network in Papua New Guinea. 
Class inequalities began to take the place of racial hierarchies. Regional differences in experiences of colonialism also produced ethnic arrogance, as some groups considered themselves more civilised, Christianised and modern than others, by virtue of longer and more intense engagement with commerce, colonial government and Christianity (Errington \& Gewertz, 1994). Others harboured simmering resentments over exploitation of land and labour by the national government or by fellow citizens (Allen, 2013; Bennett, 2002).

Political independence coincided with a transition from labour-intensive plantation economies to resource extraction. These changes in the social organisation of labour created large-scale disruption and, as Matthew Allen observed, 'one would be hard-pressed to name a single extractive project in Melanesia that has not produced violence of some form' $(2018$, p. 6). Inequality lies at the heart of all such conflict - rage that some individuals and groups are benefiting, while others are not, and frustration at the unfulfilled promises of states and corporations. After PNG obtained independence, the mining sector steadily expanded through a succession of large-scale projects (Bainton, 2010; Jacka, 2015; Kirsch, 2014). As holes were being dug and mineral wealth was being exported, international capital fuelled the expansion of the logging industry in PNG and Solomon Islands from the early 1980s, leaving a trail of environmental destruction and dashed hopes for development (Allen, 2011; Bennett, 2000; Filer $\&$ Sekhran, 1998). With a growing number of multinational resource companies operating in the region, and as thousands of international labourers and companies find employment and business opportunities in these industries (Bainton \& Jackson, 2020), contemporary resource extraction resembles a second wave of colonial expansion. Paternalistic colonial states may have been replaced by politically independent states; over time, however, these have become 'contractual states' or 'corporate states' (Kapferer, 2005) that have outsourced their development responsibilities to foreign corporations while wealth is accrued in distant lands or tax havens such as those found in Vanuatu (Rawlings, 2011).

Other forms of dispossession are at play in Vanuatu, whose independent government refused commercial logging. A strong reliance upon tourism and construction as alternative 'roads' to development has allowed international investors and local collaborators to seize large tracts of rural and urban land for tourist resorts and residential properties, dispossessing many customary landowners (McDonnell, 2017). The various land transformations unfolding in Vanuatu can be understood as forms of 
'land grabbing' or very specific examples of the 'processes of exclusion' found by Derek Hall and his colleagues in the South-East Asian context (Hall, Hirsch \& Li, 2011; McDonnell, Allen \& Filer, 2017). Although tourism provides opportunities to celebrate cultural traditions, it simultaneously exacerbates existing forms of dispossession-these 'exotic encounters' overwhelmingly shape the ways that global others regard the people of Vanuatu and the broader region as a whole (Alexeyeff \& Taylor, 2016; West, 2016).

Such transactions and extractions have created a new class of people who are both displaced and 'dis-emplaced' or, simply, 'out of place'. Now, more than ever, human migration is a pressing development issue-it is also an issue of justice, human rights and social imaginaries. Throughout the Western Pacific, people are relocating in increasing numbers in search of economic opportunities and services, safer environments or a better existence (Lindstrom \& Jourdan, 2017). Although much of this migration follows a 'rural to urban' path, some movement is also 'rural to rural', particularly to agricultural and resource frontier zones (Bainton $\&$ Banks, 2018). In these contexts, where customary forms of landownership typically prevail, land-poor migrants enter into a broad range of formal and informal arrangements to access land for residence and subsistence, which in turn generates complex social relations (and sometimes bloody conflicts) between 'insiders' and 'outsiders' or 'landowners' and 'tenants'. The scale and speed of this in-migration, particularly to frontier zones, stresses local environments, local identities and the social and political fabric of local 'landowning' communities in ways that are often not anticipated, desirable or reversible (Bennett, 2002; Koczberski, Curry \& Anien, 2015).

Some migrants find the better life they were seeking; they may obtain jobs or access to money, improved health and education for their children or a status that they could not have achieved by staying at home. Many face enormous pressure, living in entrenched conditions of unacceptable poverty, with no access to land, no real prospects and no real escape (Bainton, 2017). For a long time, it was widely held that homelessness was a not a problem in the Western Pacific - that it was structurally and socially impossible in these countries where everyone could either claim some customary connection to a 'place' or rely upon social relations for support or the so-called 'wantok system'. While anthropologists have long documented the challenges faced by rural migrants in urban centres (Levine \& Levine, 1979; Morauta \& Ryan, 1982; Strathern, 1975) and 
the social relations of informal urban 'settlements' (Goddard, 2005; Hukula, 2015; Rooney, 2017; Zimmer-Tamakoshi, 1998), the issue of homelessness has evaded sustained anthropological attention and generally only been observed in passing. However, rising homelessness in cities such as Port Moresby must be understood as a critical index of extreme inequality and broader socioeconomic shifts.

Resentment about the way wealth is being generated from local land but not shared with local people is compounded by a situation in which foreign states are seen to be engaging with the people and governments of the region in fundamentally self-interested ways. Development aid has always been tied to post-World War II geopolitical alliances and, thus, the self-interest of the donor nations. However, this aid-so important in supporting many of the projects that do make a difference in ordinary lives - is increasingly tied to political projects. Panicked about China's rising influence in the region, Western powers are seeking to entrench their status as preferred allies and development partners of Pacific Island nations. However, Australia's intransigence on the threat of climate change means that many people across the region are questioning established allegiances and looking elsewhere for support (Morgan, 2019; Teaiwa, 2019).

Perhaps the most distressing manifestation of geopolitical inequality is the implementation of Australia's offshore detention policies, which resulted in hundreds of asylum seekers being incarcerated on Manus Island in PNG and the small island nation of Nauru (Boochani, 2018). These policies contravene international human rights conventions; they also reflect broader geopolitical inequalities, as the Australian government imposes its political and economic will upon its former colonies who remain dependent upon Australian aid. The refugee-industrial complex reproduces multiple levels of antagonism between Australia and PNG, guards and detainees or 'clients service officers' and their 'clients' (Coetzee, 2019), prisoners and landowners or, supposedly, 'genuine asylum seekers' and 'illegal cue jumpers' (or the sans-papiers), to name but a few. Old and new tropes of savagery coalesce in Manus through forms of mutual mischaracterisation, as local residents and foreign prisoners adopt the white Australian fear of Muslims and ideas of racial superiority to describe each other as 'cannibals' and 'terrorists' (Rooney, 2020; Salyer, 2018) — depictions that ultimately deny human dignity. 
Let us be clear, then-these postcolonial states are not suffering from 'underdevelopment'. Rather, they are suffering from the overdevelopment of inequality-maximising and profit-maximising forms of capitalism, which transform land and resources into commodities without opportunities for meaningful labour. They are suffering from a lack of government capacity to mitigate the environmental and social harms of resource capitalism and harness and distribute its windfall profits to all citizens of the state. Finally, they are suffering the consequences of struggling to be truly self-determined in the face of conflicting pressures from the larger states surrounding them.

\section{Inequality Lived Locally: Anthropological Perspectives}

Anthropology's most lasting contribution to the study of inequality has come from its empirical focus on those who bear the brunt of capitalist expansion, those who are on the resource frontiers, those whose stories are rarely the focus of global news and those who are often not even counted in statistics. Since Malinowski's famous research in the Trobriands, ethnographic research in the Western Pacific has also inspired some of the discipline's most ambitious challenges to Western assumptions about society, economy, personhood and social relationships. The work collected in this volume engages with a range of these scholarly discussions. However, these chapters also evince unease with grand social theory that reduces complexity and overlooks social change-a reflection of the intellectual orientation of anthropologist Martha Macintyre, whose work has inspired this volume. This frustration with theoretical abstraction also reflects the pragmatics and politics of research practice. Several contributors have worked across academic and applied settings, many have done fieldwork in diverse sites across the region, and almost all have done fieldwork across decades rather than in one intensive visit. The editors are all based in Australia, a nation whose foreign policy and aid programs have direct effects on the lives of Western Pacific people. Therefore, we approach anthropological theory not as an end in and of itself, but as a means to better apprehend the lives of ordinary people. Here, we focus on five intersecting issues that have attracted anthropological attention to the lived experience of inequality: egalitarianism and hierarchy, capitalism and class, gender relations, racial inequality and local responses to inequality. 


\section{Egalitarianism and Hierarchy}

The small-scale and fluid structures of Western Pacific polities have long been a focus of anthropological analysis. Much of this analysis is orientated around typological models of political structures or cultural ideologies. Another important strand of analysis has focused less on these typological contrasts and more on historical transformations of hierarchy and egalitarianism.

In 1963, Marshall Sahlins famously contrasted the 'chiefs' of the large Polynesian kingdoms of eastern Oceania with the 'big men' of the small-scale Melanesian polities of western Oceania. In Polynesia, he suggested, a chief's power was determined by his place in an overarching political hierarchy: a nested structure of authority into which a leader was born. In contrast, power in Melanesia was personal-grounded in a leader's ability to build factions, rally allies, demonstrate generosity, call in debts and amass resources through energetic action. Sahlins later admitted that his schema was an oversimplification; more problematically, the essay suggests that Polynesians had 'advanced' more than Melanesians, an implication that Epeli Hau'ofa (1975) saw as affirming centuries of colonial racism. Sahlins' provocation is nevertheless useful in highlighting the extent to which leadership in the Western Pacific has been grounded in social relationships rather than overarching institutions.

This big man/chief model is only one of the frameworks anthropologists have used to understand political status in the Western Pacific. Roger Keesing (1985) argued that a troika of 'priest, chief and warrior' was appropriate to seaboard Melanesia, rather than the 'big man' of the New Guinea Highlands. Some anthropologists have focused on common features of Austronesian societies that stretch from Madagascar to Hawai i: founder ideologies, an emphasis on precedence and a sense of hereditary leadership (Jolly \& Mosko, 1994; more recently, see Ku \& Gibson, 2019; cf. Barker, 2019). Maurice Godelier distinguished between the Melanesian 'big men', whose authority came through control of wealth, and the 'great men', whose power came through ritual or esoteric knowledge (Godelier, 1986; Godelier \& Strathern, 1991). Scholars have used these models to understand colonial transformations of leadership; John Barker, for example, called indigenous pastors the 'new great men' of the region (2012), whereas others have documented the proliferation 
of modern paths to power through education, business and government, the reification of customary exchange activities or the combination of all of these (Bainton, 2008).

Another influential strand of scholarship on egalitarianism in Melanesia has taken inspiration from Louis Dumont. Dumont aimed to understand the configuration of values within whole societies; he depicted India as orientated around holism and hierarchy, whereas the modern West was orientated around individualism and egalitarianism. In a paper that applied Dumontian analysis to the ethnography of Melanesia, Joel Robbins (1994) argued that Dumont conflated individualism and egalitarianism and overlooked the degree to which these value orientations conflict. Robbins argued that equality is a far more central value in Melanesian societies than those of the West and that this value is realised through relationality, rather than the holism or individualism identified by Dumont. Although Dumont has been widely criticised for his ahistoricism, Robbins adopted Dumont's approach in his now-classic ethnography of Urapmin Christianity to theorise the clash of moral values in a situation of dramatic cultural change (Robbins, 2004). This Dumontian approach also animated Mark Mosko's critiques of Robbins' claim that evangelical Christianity is 'unrelentingly individualist' (Mosko, 2015) and has been influential in other work on ideologies of hierarchy and egalitarianism (Rio \& Smedal, 2008). However, as one of us argued more than a decade ago (McDougall, 2009), such Dumontian-inspired analyses of ideologies of individualism reveal little about the lived experience of individualism, particularly in an era of rapidly increasing socioeconomic inequality.

In contrast to approaches that focus on typologies and essentialist contrasts across cultures or civilisations, Martha Macintyre is among scholars who have insisted on understanding indigenous leadership, exchange, personhood and individualism in Melanesia in the historical context of colonialism, which had reorganised regional relationships, established a monopoly on violence and enforced a colonial peace that enabled an efflorescence of exchange networks (Macintyre, 1983, 1995; see also Douglas, 1979). In the context of broader interest in the 'invention of tradition' (Hobsbawm \& Ranger, 1983; Jolly, 1992; Keesing \& Tonkinson, 1982), anthropologists also turned their attention to the ways that colonial missions and administrations sought out and sometimes helped to create the office of 'chief'. In some situations, these neo-traditional roles have had profound and lasting effects, particularly when authority is grounded in the church and, more ambivalently, the state 
(see e.g. Keesing, 1969; McDougall, 2015; White, 1991). Whether they were colonial inventions or not, chiefs were proliferating all over the region in the decades following political independence, combining traditional and novel forms of power (Main, this volume; White, 1992; White \& Lindstrom, 1997).

One aspect of this transformation is institutionalisation. Post-World War II and postcolonial male leaders tended to emerge with the support of kin groups; however, their authority was also derived from the translocal structures of government administration and translocal missions. This incipient bureaucratisation or depersonalisation of authority was shortlived-power was still very personalised. For our purposes, the more important transformation is the disarticulation of power from generative relationships with kin and land. This dynamic is evident in Keir Martin's (2013) discussion of new forms of social stratification in post-disaster East New Britain. Whereas older big men accumulated and then distributed wealth, new 'big shots' mobilise relational ties to build power and access wealth (often under the name of 'tradition'); however, they are typically seen as failing to adequately redistribute the benefits (see also ZimmerTamakoshi, 1997). They are accused of forgetting about their kin, keeping everything for themselves and cutting off their relational networks to live as selfish individuals. Such laments resonate in almost every community in the Western Pacific (Bainton, 2009).

Nowhere is the alienation of power from local relationships more evident than in large-scale resource extraction projects (Filer \& Le Meur, 2017). The 'ideology of landownership' (Filer, 1997) appears to 'ground' power in localised kin groups, whereas in fact, the constitution of corporate landowning groups has served to concentrate power in the hands of individual brokers whose power is derived from companies and the state. These new 'tribal' leaders of the extractive industries are rarely accountable to the people whose interests they may claim to represent, generating the kinds of impasses that often lead to violent conflict. For the female members of these 'resource communities', the absence of male accountability is particularly stark. Although earlier forms of personalised politics were always dominated by males, kin relations and lineage structures often gave women a degree of power, particularly (but certainly not exclusively) in those matrilineally oriented islands of the Western Pacific. As Macintyre has shown in her work on gender and mining in Melanesia, the rise of extractive economies has routinely excluded women from the benefits of extraction in a more thoroughgoing and distinctly 
non-traditional way. Across Melanesia and beyond, men gain more jobs than women and have greater access to project-related wealth (Beer, 2018; Lahiri-Dutt \& Macintyre, 2006). Despite recent attempts to address the role of 'women in mining' and related industries, their employers often implicitly (and sometimes explicitly) reinforce values of male economic privilege that affect familial relations and marginalise women (Macintyre, 2017, p. 11).

\section{Capitalism and Class}

Discussions of changing political authority-the unequal distribution of power over persons within a society_are intrinsically linked to changing economic relations. Although class distinction, like racial distinction, is a form of inequality previously exogenous to the Western Pacific, class consciousness has evidently emerged across the region with some very Melanesian characteristics. As such, we use the term 'class' in both analytical and descriptive senses to describe the historically particular relationship between labour and capital that is central to political economy and, more generally, to economic inequality of various sorts, including gradations of personal and household income and wealth, distinctions between 'landowners' and 'non-landowners', 'big shots' and 'grassroots' and so forth. In this section, we chart the ways in which anthropologists have invoked class analysis and focused on the social relations of accumulation.

Anthropologists have asked how 'pre-colonial' distinctions have been altered, enhanced or erased as these societies have engaged with cash economies and state-based political systems. Pioneering fieldwork conducted in the highlands of PNG between the 1950s and 1970s sought to understand and theorise historical forms of inequality and the transitions that were occurring in the late colonial period (Strathern, 1982). This work focused on then current topics of enquiry, including relations of production (Josephides, 1985; Kelly, 1993; Modjeska, 1982), systems of exchange (Sillitoe, 1979; Strathern, 1971) and the question of whether some groups were seemingly 'pre-adapted' to the competition of market economies (Finney, 1973), all of which provided opportunities for further theorising ideas of inequality. Much of the anthropology that followed has been concerned with the twin issues of change and inequality.

The introduction of cash currencies and market economies did not completely undermine existing sociopolitical structures. Cash and trade goods were often easily absorbed into forms of ceremonial exchange and 
put to good use for social and political purposes. These changes illustrated the capacity of some ceremonial economies to absorb new objects and forms of wealth, while resisting the absorption of values and practices associated with them in the global capitalist economy. Sahlins called this process 'developman', which he contrasted with 'development', whereby introduced items are used in ways that enable people to become 'more like themselves' on a grander scale (1992). These inflationary dynamics of traditional exchange are evident in many places. As some people harness newfound wealth for customary purposes, existing sociopolitical hierarchies and systems of value are redefined (Bainton \& Macintyre, 2016) and others are pushed out of regional economies altogether (Zimmer-Tamakoshi, this volume). These changes have created new forms of distinction between what can and cannot be sold for cash (Akin \& Robbins, 1999), eclipsing any allegedly hard division between gifts and commodities (Foster, 2008; Gregory, 1982).

More epochal than the creation of new markets for foreign goods has been the transformation of land and labour into commodities. In the plantation era, some late colonial village leaders of coastal and island Melanesia were able to tap into the wealth produced; they expanded cooperative societies, bought ships, built wharfs and sometimes used the infrastructure of missions to connect to broader trading economies. The shift to extractivism reconfigured regional socioeconomic dynamics, with little accumulated wealth remaining in local hands or invested in local lands. Consequently, most people of the Pacific have now concluded that capital accumulation is happening, very clearly, elsewhere.

Many rural communities hope that resource extraction will bring 'development'. Some extractive ventures have improved the lives of some communities in the absence of the state, even if only temporarily (Jorgensen, this volume). Yet the impoverishment of many 'host communities' and the degradation and pollution of their environments expose the corporate rhetoric of 'shared value' and 'social responsibility' as self-serving constructs designed to further corporate interests. These outcomes are not simply the result of rapacious and unaccountable corporations. Political elites and dominant landowners also redirect the flow of wealth by whisking money away in offshore investments and real estate, or they consume this wealth through conspicuous forms of largesse to ensure political power and support (see Main, this volume). The extractive relations that characterise these enclaves are underpinned by unequal ownership of the means of production (land and capital), 
use of capital and land to generate profits under competitive conditions, uneven distribution of the burdens and benefits of extraction, groups of customary landowners who expect privileged access to the mineral wealth generated from their lands (and the jobs and business contracts created by these projects) and groups of people who are compelled to sell their labour to subsist (Bainton, this volume). To the extent that different actors succeed in their different endeavours, their accumulation squeezes others out or suppresses their rights and interests, reinforcing and sometimes deepening the inequalities from which it all began.

By the 1990s, anthropological research was exploring how class ties were overtaking the ties of family, clan or even regional identities, as elites and the new urban middle class sought ways to distinguish themselves from their rural relatives (Gewertz \& Errington, 1999). While the gap between the grassroots and the big shots continues to grow unabated, the waged and salaried working class or middle class also continues to expand its ranks (Cox, 2018, this volume). This growth has created additional forms of labour stratification-some people working for resource companies and other multinational companies form a kind of 'labour aristocracy', while public sector employees survive on more modest or meagre wages with fewer cheques and perquisites (Filer, this volume; Golub \& Rhee, 2013). The overall growth in educational opportunities also means that the number of people leaving school and university has outstripped the opportunities for meaningful employment, producing a disillusioned and disaffected generation of educated citizens with fewer prospects for the future (McDougall, this volume). The rising cost of urban life and the insecurity and instability of employment and other livelihood opportunities (Sharp et al., 2015) has created previously unknown levels of precarity among town and city dwellers as the myth of subsistence affluence is replaced by the reality of urban poverty.

\section{Gender Relations}

Scholars and popular commentators who characterise the Western Pacific as 'egalitarian' tend to focus exclusively on relationships among men (Jolly, 1987). Like other feminist anthropologists all around the world (see especially Reiter, 1975; Rosaldo, Lamphere \& Bamberger, 1974), scholars of the Western Pacific were interested in how one could understand the apparent universality of male political dominance in ways that did not smuggle in distinctly Euro-American or Western cultural models. Feminist 
historians and anthropologists sought to retrieve women's voices from historical archives and to understand the ways that indigenous forms of patriarchy were transformed by the patriarchal structures of colonialism, capitalism and Christianity (Barker, this volume; Douglas, 2003; Jolly \& Macintyre, 1989; Ram \& Jolly, 1998).

The quest to understand apparently universal gender inequalities without reproducing the culture-bound assumptions of Western social theory lies at the centre of Marilyn Strathern's influential Gender of the gift (1988). Strathern suggested that gender inequality can be explained in terms of the degree to which a person can constitute themselves as an individual or a member of neatly bounded social groups. Due to their reproductive capacity (women's ability to birth others from their own bodies), women were far less able to 'cut' the relationships that bound them to others. Men, she argued, could (at least sometimes) emerge from these networks of relationships to stand as autonomous, agentive and self-contained bodies. Crucially, these entities could be the individual person or a collective clan group-both were social forms that denied connections to the others that made them. Strathern was not uninterested in historical change (see e.g. Strathern, 1987); however, by mobilising 'fictional' binaries of 'Us/Them', 'West/Melanesia' and 'Gift/Commodity', she pushed any analysis of colonial transformations to the background. This caused an apparent schism between the so-called 'new Melanesian anthropology' and the 'new Melanesian history' (see Foster, 1995; Josephides, 1991; Keesing \& Jolly, 1992; Scott, 2007).

Macintyre was among those who most powerfully bridged the polarities of this era, drawing on her deeply historical understanding of exchange relationships and gendered personhood in the Massim to challenge both the romanticism and presentism of the emerging orthodoxies of 'Melanesian personhood'. She argued that the efflorescence of exchange systems, which were so central to the constitution of persons in the region, was profoundly shaped by forcible colonial pacification (Macintyre, 1983). Macintyre urged theorists of Melanesian personhood to attend to the ways that these ideologies and practices were manifest through not only the constructive constitution of persons through exchange but also the violent destruction of bodies through warfare (Macintyre, 1995). Macintyre's clear-eyed attention to colonial transformations and the darker side of indigenous cultural ideologies and practices informed her 
ongoing focus on gender-not only as a principle of social organisation but also as an axis of discrimination that truncated the lives of women and girls in PNG and beyond.

Scholars committed to understanding contemporary gender inequality in the Pacific turned attention to both colonial political economies and Christianity. The landmark Family and gender in the Pacific, edited by Margaret Jolly and Martha Macintyre (1989), showed that current gender inequality is not a simple continuation of supposedly traditional customs, as is too often suggested by so much contemporary commentary on high rates of gender-based violence in the Pacific. In many cases, introduced forms of male domination have both overlaid and exacerbated indigenous patriarchy and opened new possibilities for contestation. European Christian missions and contemporary indigenous Christianity have been particularly paradoxical in this regard (Choi \& Jolly, 2014; Tomlinson $\&$ McDougall, 2013). Victorian-era missions glorified the domestic role of women, viewing their proper place as in the home rather than in the agricultural work that is the very definition of productive femininity in most of the Western Pacific. Yet Christianity also opened new spaces for socialisation, particularly the critically important women's fellowship groups that emerged (along with non-church affiliated women's cooperatives) throughout the 1960s and 1970s in most Christian churches in Melanesia. Sometimes moving from localised concerns to broader forms of activism and peace movements, these church groups were the 'missing rib of indigenous feminism' according to Anne Dickson-Waiko (2003; see also Barker, this volume).

The commodification of traditional forms of exchange has sometimes had deleterious effects on gender relations. This is especially the case where 'bridewealth' payments - understood by anthropologists as an acknowledgement of relations of indebtedness across kin or lineage groups and opening the way for lifelong exchanges—are reframed around the logics of commodity exchange as the simple purchase of women, or what is commonly called 'bride price' payments (Filer, 1985; Jolly, 2015). Holly Wardlow has shown how Huli women in the highlands of PNG have reacted in rage to this sort of alienation from their own reproductive power (2006). Other work on PNG women in the modern economy suggests a slightly more positive trajectory. Writing of women who have leveraged education and skills for salaried positions in the civil service or mining economy, Macintyre argued that 'money changes everything' (2011). Able to avoid or disengage with marital relations that have become 
both increasingly important and increasingly oppressive in many pockets of PNG society, these modern women are able to become the heads of their own households, choosing to invest in their own relationships with extended kin (Spark, 2017, 2019; Zimmer-Tamakoshi, 1993, 1998). From this perspective, rather than merely reproductive capacity or biological sex, it is 'position' in a broader political and economic space that shapes experiences of gendered personhood and agency (Cox \& Macintyre, 2014; Macintyre \& Spark, 2017; Spark, Cox \& Corbett, 2019).

Changing gender relations, particularly the new autonomy of salaried urban women, is sometimes experienced as deeply threatening by Melanesian men, particularly in those contexts in which they see their own possibilities narrowed and aspirations squashed. Anthropologists have documented such backlashes, which often embrace romanticised notions of neo-traditional male-dominated kastom and reject the idea of human rights (seen here as 'women's rights') (Macintyre, 2012; Taylor, 2008a). To this end, anthropologists are paying greater attention to the ways that Melanesian masculinities are 'changing' (Taylor, 2008b) and 'moving' (Jolly, 2008) as men meet the challenges of rapidly changing environments and societal expectations, blending received modalities of gender, sexuality, economy and authority with exogenous forms. The historical processes of colonialism, Christian conversion, market penetration and urbanisation have upset and displaced once 'hegemonic' forms of masculinity, as the flux and change of Melanesian gender relations has given rise to a plurality of masculinities and 'emergent' expressions of these new masculine ideals (Biersack, 2016; Jolly, 2008; Jolly, Stewart \& Brewer, 2012; Munro, 2017; see also McDougall, this volume; ZimmerTamakoshi, this volume).

\section{Racial Inequality}

The people of the Western Pacific were subject to shocking manifestations of colonial racism. Racist ideologies in the colonial era justified exploitative labour practices; these ideologies were later mobilised in the era of decolonisation to argue that Melanesians were not, and might never be, ready for independence (Banivanua-Mar, 2006, 2016). The region was also among those sites where the early 'science of race' was developed (Douglas, 2008). Euphemised racial attitudes are continuously encountered in the postcolonial era among ex-colonisers, neo-colonial institutions and their agents and in local strategies of identity and 
resistance. As Tarcisius Kabutaulaka has argued (2015), the legacy of European racism continues to shape how outsiders see and interact with the region; more disturbingly, perhaps, people of the Pacific have themselves taken up some of this racial thinking in their attitudes towards one another.

Racial inequality in postcolonial Melanesia has been transformed as it intersects with other forms of inequality. In some situations, new class inequalities have eclipsed old racial hierarchies. For instance, these patterns are evident in the ways that some urban elites in PNG project a 'cargo cult' or handout mentality on to the rural grassroots (see Cox, this volume). However, the emergence of class differences, and a strong awareness of these distinctions and interests, has not erased the legacies of racist regimes, the persistence of racial discrimination and persecution or forms of racial scapegoating. Ceridwen Spark, for example, has documented the racialised experience and humiliations of professional Melanesian women working in Australian development programs (2020). The misconception that 'racial differences are materially true and determine the physical, intellectual, moral or social qualities of identifiable groups' (Douglas, 2008, p. 3) continues to shape sociopolitical relations within Western Pacific nations and in engagements with other Pacific Islanders, people of European descent and Asian descent. Race, in other words, no longer simply means white supremacism.

Postcolonial racial dynamics continue to pivot around longstanding EuroAustralian distinctions. The legacies of colonial racial categories are most tellingly evidenced in the persistence of terms like 'mixed race' or 'hapkas' (Goddard, 2017; Winter, 2017) to describe people of 'mixed parentage' (Johnson \& McGavin, 2017). Just as racialised negative self-perceptions are produced when colonial attitudes are internalised (Bashkow, 2006), negative attitudes towards Asian migrants have a similar colonial legacy and tend to mirror the ways in which some whites denigrate Asian people. Melanesians of all class status can be found reproducing the racist discourse of colonialism with respect to Asian migrants. In PNG, Asians are frequently imagined as possessing a rapacious culture and an absence of morality, which is then rhetorically contrasted with Melanesian sociality and Christian virtues (Cox, 2015). While many Melanesians enter into advantageous arrangements with Asian migrants, and many people draw a distinction between 'old' and 'new' Asians (Crocombe, 2007), there remains a deep suspicion and resentment towards Asian residents who are accused of buying their way into the region and taking 
up the few economic opportunities open to poor islanders (Smith, 2013). These sentiments have elicited a kind of 'reactive nationalism' (Barclay, 2012) that has occasionally erupted into large-scale riots targeting Asian businesses in major urban centres. This rising anti-immigrant racism on the part of those who have missed out on the benefits of globalisation again links the dynamics of the Western Pacific to global metropolitan politics, where the victims of neoliberal policies that have gutted the welfare state seem to direct their anger at migrants rather than the leaders responsible for their misery.

\section{Local Responses to Inequality}

Studies focusing on the dramatic new forms of inequality emerging in the Western Pacific paint a dire picture. It is difficult to see how local processes of levelling and commitment to community wellbeing could make a dent in the inequality-maximising forms of global capitalism that are inserting themselves in every corner of society. A glimmer of hope may be found in the renewed focus on equality in the UN Sustainable Development Goals and the possibility that these global frameworks will influence policies and priorities on the ground. Inequality is finally being recognised as a universal issue and global crisis; this may signal a longoverdue shift in emphasis from perpetual growth to a more justice-centred future.

Moreover, the history of Melanesia is full of movements in which people have worked together to bring about a vision of a common good. As Tracey Banivanua-Mar observed, 'Indigenous peoples found and practised discrete, and often localised, forms of self-determination that resisted administrative borders of convenience and developed Indigenous alternatives to national sovereignty' (2016, p. 151). However, rather than being recognised as movements for political autonomy, 'almost universally, these were dismissed as cargo cults and the mere incessant talk of custom' (2016, p. 167). The label 'cargo cult' drew attention to only one aspect of such movements: an attempt to access material goods and wealth possessed by whites. Colonial attempts to contain these movements, and anthropological analysis seeking to understand them, have emphasised the millenarian and messiantic aspects of these movements and seen them as adjustments to aspects of modern life (Burridge, 1971; Lawrence, 1964; Mead, 1956). More recent work, such as that of Banivanua-Mar, has viewed such movements as responses to colonial inequality and oppression, as expressing a desire for moral equivalence and as embedded 
in translocal networks (Errington \& Gewertz, 2004; Keesing, 1992; Lindstrom, 1993). David Akin (2013) argued that the Maasina Rule movement in Solomon Islands should be viewed as a struggle for civil and political rights in the late colonial British Empire and part of the broader story of civil rights movements throughout the world. In common with other anti-colonial and civil rights movements of the mid-century in every corner of the world, these Melanesian autonomy movements were social and spiritual, rather than technical or bureaucratic. Echoes of these movements can be found throughout the Western Pacific and beyond, where some of these activities have become institutionalised as indigenous churches and regional political organisations, reflecting the persistence of normative modernist desires and the uneven distribution of wealth and opportunity.

In the past decade or so, this sense of hope and the desire for social justice has been most forcibly directed towards the elimination of 'gender violence' or 'family and sexual violence' (as it is commonly termed in PNG) and sorcery accusation-related violence. In response to the apparent upsurge in gender-based violence in all its dreadful manifestations, a variety of 'reformist' movements have emerged at the local and national levels. These movements, and their agents, must navigate a path between their commitment to the ideology of universal human rights and local cultural orders that are often deemed (by outsiders in particular) as obstacles to be overcome. These imposed hierarchies-between the universal and the particular-create specific challenges on the ground for the task of 'translating' and 'transplanting' the international human rights regime. Similar to earlier movements concerned with social transformation, anthropologists have been particularly well placed to undertake historically informed ethnographic analysis of these new rights-based movements to understand the history of a globalising Western Pacific (Biersack, Jolly \& Macintyre, 2016; Hildson et al., 2000).

\section{Making Sense of Inequality: Intersectionality in the Western Pacific}

A longstanding tension in anthropology between celebrating diverse ways of being and calling out injustice has re-emerged in debates about whether anthropology is overly focused on the 'suffering subject'-those people living in pain and poverty or under conditions of violence and 
oppression (Knauft, 2019; Ortner, 2016). Robbins (2013), for example, has made a case for an 'anthropology of the good' that seriously engages the aspirational and idealising aspects of people's lives. In contrast, Paige West (2018) has criticised what she sees as a worrying trend in anthropology to find hope in everything; perhaps we must simply learn to sit with suffering more? Anthropologists who continue to work in the Western Pacific cannot escape the increasingly harsh conditions that characterise many rural and urban settings and shape local aspirations and the potential for the future.

Making sense of these conditions is no easy task. While popular attention is often focused on the distribution of wealth and income, inequality has many other dimensions that often intersect with and compound each other, including gender, race, class, age, ethnicity, disability and sexuality, to name but a few. As the chapters in this volume show and the foregoing discussion illustrates, it is critical that we attend to the transformation of inequality, not simply its persistence or expansion. Wardlow (2018) and various others have suggested that we can usefully understand these transformations through the lens of intersectionality, which, in the most basic sense, is a metaphor for the ways that different forms of inequality and discrimination 'intersect' dynamically with each other-picture a person at a junction with different inequalities speeding towards them or, perhaps, to use more island-like imagery, a person caught in a convergence of currents. This is a not a grand theory but instead a prism for observing complexity in the world-the events and conditions of social, economic and political life, and experiences of the self, are rarely shaped by single factors. They are formed and reproduced through an assorted array of factors in mutually influencing ways. These convergences create obstacles and impediments in individual lives that are not always easily understood or identified within conventional modes of thinking about specific inequalities or through single-axis frameworks (e.g. 'class' or 'race'). ${ }^{3}$ Rather than treating race and gender, or other dimensions and categories, as simple add-ons to an economic base, intersectionality demands a multidimensional and multiscale view of inequality-each of the chapters in this volume tackle this head-on. As has often been noted, capital is intersectional - it intersects with the bodies that produce labour,

3 Kimberle Crenshaw (1989) is often credited with coining the term 'intersectionality' (although the core ideas of intersectionality emerged earlier in various texts and in practice). See also Jolly's Interlude (this volume). 
the places where resources are extracted and the racialised, gendered and class-based structures that produce and enhance the accumulation of wealth.

By focusing on intersections and transformations, we are forced to attend to the temporal and spatial dimensions of specific kinds of inequality in this region. Attention to historical dimensions assists in identifying forms of change and continuity that unfold over time-allowing us to simultaneously 'look back' and critically re-assess received assumptions about past practices and contemporary conditions and to 'look forward' to future prospects. That is, we can begin to understand how forms of inequality between people are historically produced. We are also forced to move beyond simple rural-urban binaries and dispel myths that underpin regional imageries of land-connected subsistence farmers (or images of 'rural affluence') to attend to the disparities that exist among rural families, or what can be understood as 'relative rural poverty' (Burton, 2018; Wardlow, 2018). Quite simply, some rural families are poorer and more vulnerable than others. The diversity of this region militates against broad generalisations, highlighting the need to consider unique intersections or conjunctures in different times and places. Likewise, by considering the geographical dimensions of inequality, our attention is directed to the uneven flow of things-capital, power, ideas and materials-across the ocean and the landscape. This allows us to grasp the ways in which some places have benefited historically from relationships of dispossession and the transfer of wealth from elsewhere and how their present condition is partly the result of such inequities (Bebbington \& Humphries Bebbington, 2018). These geographies of power and inequality shape place-making processes and the lives of individuals living in the Western Pacific.

The authors in this volume analyse the enduring structures and experiences of inequality in the communities of the Western Pacific and the forms of subordination, dispossession, indignity and humiliation that constitute their unequal lives, in addition to the multiple counter-movements and forms of agency that emerge in response to these transformations. Taken as a whole, this volume presents a broad picture of intersecting inequalities, heterogeneous forms of violence and oppression and diverse kinds of dispossession, in addition to the structures, institutions, beliefs and assumptions that underpin and reproduce them. 


\section{The Chapters}

The chapters in this volume focus on contemporary transformations of inequality, as gendered, race- and class-based inequalities intersect in novel ways to entrench existing inequities and create new varieties of vulnerability. The authors consider not only multiple dimensions of inequality but also multiple scales: local, national, regional and global/ world historical. Through close ethnographic scrutiny, they highlight how relationships between seniors and subalterns, agents and patients, patrons and clients, vary across scales-that is, how different scales of inequality emerge in lived experience. For example, while it might be argued that, from a regional perspective, PNG is subordinate to Australia, from a national perspective, the folks driving around in Maseratis during and after the APEC meeting mentioned at the outset are hardly subaltern. These sorts of multiscale inequalities, found throughout the volume, may also be understood as a kind of intersectionality in the generalised metaphorical sense of the term.

These forms of socioeconomic inequality are also reflected in forms of epistemological inequality; as anthropologists have long observed, some people's knowledge is valued more than others. As Indigenous anthropologists globally and in the Western Pacific have attested (Hukula, 2018; Rooney, 2018), they face multiple barriers to participation in Western-centric institutions, let alone sustained interrogation of alternative values and epistemologies. We recognise that such inequality is evident in this volume: of all contributors, only John Aini and Dora Kuir-Ayius are from the Western Pacific.

Several chapters in the volume provide a frame for thinking about the possibilities and limitations of anthropological research, knowledge production and persistent forms of epistemic inequality. Paige West and John Aini analyse the costs and exploitative relations that often underpin the production of knowledge but are rarely acknowledged or accounted for. In places like PNG, small locally based non-governmental organisations (NGOs) play a critical role in facilitating the production of conservation and environmental knowledge. These local organisations are located within a broader field of patron-client relationships between small NGOs and 'big international NGOs'. But the structural inequalities contained in conservation funding cause material inequalities that create the conditions whereby small NGOs must undertake a great deal of unpaid work 
and incur a range of social and economic debts to service the requests (and opportunities) presented by large NGOs. The capacity to mobilise networked social relations of obligation and reciprocity is critical in meeting these requests. This work is frequently rendered invisible (and structural inequalities are hidden) when outsiders naively interpret these activities as expressions of 'island hospitality' — and this forms yet another manifestation of the casual and insouciant expression of white privilege. Anthropologists are reminded that much of their work, and the knowledge they produce, is underpinned by debts that can never be repaid.

In a similar vein, Simon Foale exposes the epistemological injustice that arises from the false hierarchy between the so-called 'soft' and 'harder' sciences. Within metropolitan centres of knowledge production, different kinds of knowledge are valued differently. Whose knowledge production is recognised, and why, matters a great deal. Charting his own disciplinary journey from marine biology to anthropology, settling on a form of critical political ecology, Foale argues against the undeserved hegemony of natural scientists in cross-disciplinary projects on environmental problems in the Pacific. He exposes the ways in which natural scientists reinvent an 'antipolitics machine' of reductionist, managerial and deeply neo-colonial social science, which studiously ignores so much of what anthropology has contributed, and can continue to contribute, to understanding and addressing the complex nexus between environmental problems and inequality in the Pacific.

Taking up ideas of attachment and partibility that have been so central to theories of Melanesian personhood, Melissa Demian suggests that anthropologists_like pigs (Macintyre, 1984)—are 'semi-alienable'. Having worked first in Suau in Milne Bay, Demian finds herself thinking through the categories of Suau language and being identified by Papua New Guineans not only as a European but also as being from Suau, as the PNG place from which she 'comes from'. Tracking back and forth between her experience in Suau and the urban contexts where she has later undertaken applied research on gender and family violence, her chapter analyses the awkward but productive relationship between anthropologists and the communities with whom they work and the sort of knowledge that emerges through these collaborations.

Susan Hemer approaches the question of knowledge production from a rather different angle by considering the multiple scales of inequality that support the spread of tuberculosis (TB) in the Lihir Islands in 
PNG, which are also host to a large-scale gold mining operation. Global health policies and guidelines may acknowledge the socioeconomic and political contexts of diseases like TB; in practice, though, these treatment regimens are singular, vertical and context-free. As these global policies are translated into national and local contexts, important inequalities are often obfuscated and compounded because treatment programs focus on individual failures and responsibilities rather than the relationship between this disease and structural factors such as poverty and uneven development. The mining operation has given many Lihirians better access to health services than other Papua New Guineans, but TB is nevertheless flourishing in Lihir. Hemer argues that this is partly the result of health programs that highlight individual or cultural failures and suppress the specific social and gendered inequalities that influence the extent to which some people will seek diagnosis and continue with their treatment. By ignoring inequality, these programs only help to intensify it.

Several chapters deal with the transformation of gendered inequalities, including changing notions of masculinity. In a historical analysis of marriage practices in Maisin society, John Barker upends stereotypes of indigenous patriarchy and missionary impacts to demonstrate how gender relations were intensely transformed through more than a century of engagement with Christianity. As Anglican missionaries waged a longterm campaign to impose sacramental marriage, Maisin communities have navigated a path between customary obligations that are grounded in the traditional ideal of balanced exchange relationships between families and Anglican orthodoxy that regards marriage as a lifelong commitment to one's partner and the church itself. Just as the traditional ideal of 'amity' was better understood as a point of reference for measuring actualities, the Anglican ideal of equality was not necessarily achieved in practice. Inequalities between men and women, and young and old, are brought to the fore as different groups attempt to move between mission rules and customary obligations and as enduring tensions in marriage are transferred to the church. It was the establishment of the Mother's Union, a local women's church group, that has had the most contradictory effects, because it simultaneously provides women with a platform for greater economic autonomy (disrupting male control over economic matters) and enables older women to exert authority over younger women and usurp the power of the clergy. 
As is the case with medical care provided by missionaries and miners, the benefits of schooling are unevenly spread across geographical regions, social classes and genders. Global efforts to expand access to schooling have led to children spending longer in school and have reduced gender disparities in schooling; nevertheless, rural and poor students often find that, by the time they achieve a qualification, it is no longer sufficient to obtain a job. Debra McDougall's chapter analyses the experiences of Solomon Islander students who have joined a remarkable vernacular language school. All students and teachers she interviewed were critical of the conventional school curriculum, which begins with English-a language few children understand. Her chapter reminds us that language is a crucial aspect of inequality and explores why some of the contradictions of schooling are experienced differently by men and women. Both young women and men saw how learning the grammar of their own language helped them in formal schooling, but only young men spoke of the shame they experienced in school and feelings of worthlessness when they failed exams or were unable to find work. The frustration and sense of 'lostness' she describes are evident across the collection, particularly in the chapter by Gewertz and Errington. In Ranongga, though, this frustration is being addressed in a positive way.

Deborah Gewertz and Frederick Errington reflect upon Sepik settlement life on the outskirts of Madang, where a form of 'stingy egalitarianism' has emerged as a survival strategy in response to increasing levels of precarity; food and generosity are scarce and unruly gangs of disaffected young men abound. Social relations have descended into a form of pre-emptive levelling, in which individuals refuse to let others get ahead. The insecurity and unpredictability of settlement life offer few opportunities for people to invest in cultural traditions or to be more like themselves, as Marshall Sahlins would have it. Under these conditions, standing out is difficult and unwise. The study of settlement life involves pitfalls for researchers and their subjects and their research presence-although grounded in longstanding and enduring relations of reciprocity with people from the Sepik region-has produced unwanted and unanticipated effects. Their presence provided unique opportunities for some individuals to get ahead, albeit temporarily, exacerbating existing jealousies and contentions with other people. Much like West and Aini's contribution, their confronting experience serves as a timely reminder of the sometimes-unintended consequences of our presence as researchers and the relationships we form. 
John Cox examines how the growing gap between PNG's urban middle class and the nation's rural poor, the 'grassroots', is shaped and reproduced. Whereas middle-class aspirations are often framed in terms of global discourses of progression and prosperity, when the grassroots express their desires for development, they are frequently disparaged and dismissed as lazy 'cargo cultists' waiting for 'something for nothing'. Different moral evaluations of desire legitimatise the accumulative practices of elites and render the aspirations and demands of their poorer followers immoral, greedy and superstitious. When a series of 'fast money' schemes swept across the region towards the end of the twentieth century, rural and urban investors alike sought their fortunes in these schemes. Many hopeful investors lost a lot of money-popular accounts characterised middleclass investors as rational and sophisticated (even if the majority failed to make a profit), whereas their grassroots counterparts were cast as gullible and simple. These emerging class distinctions are being further reinforced as the moral economy that binds rural and urban relatives-and ensures some form of wealth redistribution-is being restructured around donorclient models as members of the middle class begin to see their rural kin as subjects who must be mobilised for development.

Dan Jorgensen's chapter links back to the theme of masculinities and economic stratification and forward to the final chapters that discuss inequality and resource extraction. Jorgensen explores the possibilities for conducting a 'remote ethnography' of the present, a kind of 'processual anthropology'. Focusing on two unexpected events that dramatically affected the lives of Telefomin people and others living in the hinterland of the giant Ok Tedi mine in PNG, Jorgensen combines both analysis and a form of 'witnessing' to emphasise the structural inequalities that shape Telefomin futures. In the lead up to 2011, there was an unprecedented outbreak of violent attacks against alleged witches in a rural village. This was later followed by a prolonged period of drought in 2015, which had a devastating effect upon the region. When critical river transport routes became unnavigable due to insufficient water flow, the mining company suspended operations. This also provided the necessary 'shock' to enact another major change and close the mining town, raising critical questions about the future of the mine and, ultimately, the region. Jorgensen demonstrates how historical perspectives demand that the ethnography of the present necessarily points towards the future, which in turn highlights the contingent nature of events. These cases also neatly illustrate how the multiple scales of inequality emerge in daily life. The local beneficiaries of the mine may be perceived as (illegitimate) superiors to the 'lost boys' 
(or wayward men) in the village. Yet, these same beneficiaries are also subalterns without agency in the face of the company's decision to effectively close the local town.

Laura Zimmer-Tamakoshi charts the long-term engagement with capitalism and the resulting transformations that have given rise to new forms of inequality and uncertainty among the Gende, who reside in the Bismarck Mountains in Madang Province. Gende social relations have been completely reorganised around the political economy of extraction and the promise of instant wealth. The ceremonial exchanges that once constituted a kind of 'moral economy' among the Gende and their neighbours have been transformed beyond recognition, as men compete with huge sums of money to secure their position among an elite set of landowners to lay claim to land and other forms of wealth. The rise of new power brokers has left many young Gende males feeling disempowered, creating intergenerational tensions and troubled masculinities. But the most novel (and potentially destabilising) form of inequality to emerge is among women - not only the widening gap between males or between men and women - as some women have been able to capitalise on new economic opportunities to subvert patriarchal power structures and cut their social ties to assert new forms of autonomy.

Michael Main describes a similar set of generational changes in the context of the massive Papua New Guinea Liquefied Natural Gas (PNG LNG) project that covers vast tracts of Huli territory in Hela Province. Not only has this project failed to meet local expectations for development and change, but it has also reconfigured expressions of male authority, much like other extractive ventures in the region. In the 1950s, Robert Glasse described a system of Huli political authority that drew a distinction between expert knowledge and the ability to accumulate wealth. The PNG LNG project has created the conditions for these two types of leadership to converge, as those who are able to make successful truth claims about land and genealogies are able to secure huge quantities of wealth from the project, which they then convert into more political power. The adoption or 'invention' of the role of 'paramount chief', in what was formerly regarded as a 'chiefless society', has corresponded with increased levels of competition and bloody conflict and the elite capture of wealth.

While much discussion has focused on the relationship between extractive companies and the communities affected by their operations, much less has been written about the Papua New Guineans employed 
in the extractive industries, some of whom are recruited because they belong to project-affected communities, while others are recruited from further afield. Colin Filer addresses this gap in his chapter on the forms of inequality and mobility that are created, moderated and accentuated through the employment opportunities created by large-scale mining in PNG. The mineral policy framework in PNG creates a series of 'zones of entitlement' around each major project, which entitles different sections of the population to different project-related benefits, including employment and business contracts. There are good reasons to believe that the extractive sector workforce is more mobile, in both a geographical and social sense, than any other sectoral workforce in PNG; elements of this workforce may even be considered as a sort of 'labour aristocracy' within the wage-earning population. The relationship between the social and geographical mobility of these workers, the inequalities within and beyond their ranks and the extent to which they have become detached from the moral economy that binds other Papua New Guineans to networks of kinship and affinity within the so-called 'wantok system' would suggest that some jobs are better for 'development' than others.

In the final chapter, Nick Bainton considers the unequal social relations that have emerged within and across the different 'zones of entitlement' that surround the Lihir gold mine and the various counter-movements that have arisen in response to the asymmetries of power and wealth between the company and the community. The difference between the expectations of the community for corporate-funded social and economic development in return for access to their land and the ways in which the company has enacted its commitment to the ideology of 'corporate social responsibility' has resulted in a state of mutual incomprehension. Coupled with the impacts from the mine, this has produced a strong sense of indignation; community members frequently accuse the company and the government of reducing them to mere 'spectators on their own land'-an expression that reflects a specific type of subjectivity that accompanies large-scale resource extraction. Local outrage over this situation often manifests in a remarkable expression of negative agency, as the customary landowners of the mine lease areas use a traditional taboo marker (known locally as a gorgor) to menace the mine.

Bridging the substantive chapters and the personal reflections on Martha Macintyre's legacy that conclude this volume, Margaret Jolly's 'Interlude' reminds us of the intersecting inequalities of gender, race and class that are foregrounded throughout the preceding chapters and also in so much of Martha's work. Jolly underscores three key characteristics of Martha's 
scholarship: a sustained critique of class and gender inequality, insistent attention to historical transformation and a strong ethic of ethnographic fidelity. After weaving together themes from each of the papers, Jolly brings us back to the vignette from the Pacific Islands Forum that featured at the outset of this chapter to underscore the urgency and the gravity of the inequalities inherent in our shared climate emergency. In our increasingly overheated world, existing inequalities will only assume more perverse and tragic forms. It is difficult to be optimistic about the future when the fossil fuel industries and Australia's sclerotic political system seem incapable of change. In these troubling times, Jolly reminds us of the best that anthropology can offer, exemplified in Martha's work: the capacity to bring activism and scholarship to bear on the most serious issues of our time, to genuinely engage those who have much to lose and those who have much to contribute.

\section{References}

Akin, D. (2013). Colonialism, Maasina rule and the origins of Malaitan kastom. Honolulu, HI: University of Hawai'i Press.

Akin, D. \& Robbins, J. (1999). Money and modernity: State and local currencies in Melanesia. Pittsburgh, PA: University of Pittsburgh Press.

Alexeyeff, K. \& Taylor, J. (2016). Touring Pacific cultures. Canberra, ACT: ANU Press. doi.org/10.22459/TPC.12.2016

Allen, M. G. (2011). The political economy of logging in Solomon Islands. In R. Duncan (Ed.), The political economy of economic reform in the Pacific (pp. 277-301). Manila, Philippines: Asian Development Bank.

Allen, M. G. (2013). Melanesia’s violent environments: Towards a political ecology of conflict in the western Pacific. Geoforum, 44, 152-161.

Allen, M. G. (2018). Resource extraction and contentious states: Mining and the politics of scale in the Pacific Islands. Singapore: Springer Singapore.

Alvaredo, F. et al. (2018). World Inequality Report 2018. World Inequality Lab. Retrieved from wid.world/world-inequality-lab/

Aqarau, T. (2020, 9 April). COVID-19 and Solomon Islands: The first casualties and possible ramifications. DevPolicyBlog. Retrieved from devpolicy.org/covid-19and-solomon-islands-the-first-casualties-and-possible-ramifications-20200409/ 
Bainton, N. A. (2008). Men of kastom and the customs of men: Status, legitimacy and persistent values in Lihir, Papua New Guinea. The Australian Journal of Anthropology, 19(2), 195-213.

Bainton, N. A. (2009). Keeping the network out of view: Mining, distinctions and exclusion in Melanesia. Oceania, 79(1), 18-33.

Bainton, N. A. (2010). The Lihir destiny: Cultural responses to mining in Melanesia. Canberra, ACT: ANU E Press. doi.org/10.22459/LD.10.2010

Bainton, N. A. (2017). Migrants, labourers and landowners at the Lihir gold mine, Papua New Guinea. In C. Filer \& P.-Y. Le Meur (Eds), Large-scale mines and local-level politics: Between New Caledonia and Papua New Guinea (pp. 313351). Canberra, ACT: ANU Press. doi.org/10.22459/LMLP.10.2017

Bainton, N. A. \& Banks, G. (2018). Land and access: A framework for analysing mining, migration and development in Melanesia. Sustainable Development, 26(5), 450-460.

Bainton, N. \& Jackson, R. T. (2020). Adding and sustaining benefits: Largescale mining and landowner business development in Papua New Guinea. The Extractive Industries and Society, 7(2), 366-375. doi.org/10.1016/j.exis. 2019.10.005

Bainton, N. A. \& Macintyre, M. (2016). Mortuary ritual and mining riches in Island Melanesia. In D. Lipset \& E. Silverman (Eds), Mortuary dialogues: Death ritual and the reproduction of moral community in Pacific modernities (pp. 110-132). New York, NY: Berghahn.

Banivanua-Mar, T. (2006). Violence and colonial dialogue: The Australian-Pacific indentured labor trade. Honolulu, HI: University of Hawai'i Press.

Banivanua-Mar, T. (2016). Decolonisation and the Pacific: Indigenous globalisation and the ends of empire. Cambridge, England: Cambridge University Press.

Barclay, K. (2012). Development and negative constructions of ethnic identity: Responses to Asian fisheries investment in the Pacific. The Contemporary Pacific, 24(1), 31-64.

Barker, J. (2012). The enigma of Christian conversion: Exchange and the emergence of new great men among the Maisin of Papua New Guinea. In L. Dousset \& S. Tcherke'zoff (Eds), The scope of anthropology: Maurice Godelier's work in context (pp. 46-66). Oxford, England: Berghahn.

Barker, J. (2019). Mixed grammars and tangled hierarchies: An AustronesianPapuan contact zone in Papua New Guinea. Anthropological Forum, 29(3), 284-301. 
Bashkow, I. (2006). The meaning of whitemen: Race and modernity in the Orokaiva cultural world. Chicago, IL: University of Chicago Press.

Bebbington, A. \& Humphreys Bebbington, D. (2018). Mining, movements and sustainable development: Concepts for a framework. Sustainable Development, 26(5), 441-449. doi.org/10.1002/sd.1888

Beer, B. (2018). Gender and inequality in a postcolonial context of large-scale capitalist projects in the Markham Valley, Papua New Guinea. The Australian Journal of Anthropology, 29(3), 348-364.

Beldi, L. (2018, 17 October). PNG government splurges on 40 Maseratis for APEC leaders as polio returns to the country. Australian Broadcasting Corporation. Retrieved from www.abc.net.au/news/2018-10-12/png-splurgeson-40-custom-maseratis-as-polio-returns/10366734

Bennett, J. A. (2000). Pacific forest: A history of resource control and contest in Solomon Islands, c. 1800-1997. Cambridge, England: White Horse Press.

Bennett, J. A. (2002). Roots of conflict in Solomon Islands. Though much is taken much abides: legacies of tradition and colonialism (SSGM Discussion Paper 2005/5). Retrieved from dpa.bellschool.anu.edu.au/experts-publications/publications/ 1541/roots-conflict-solomon-islands-though-much-taken-much-abides

Biersack, A. (2016). Introduction: Emergent masculinities in the Pacific. The Asia Pacific Journal of Anthropology, 17(3-4), 197-212. doi.org/10.1080/144422 13.2016.1186215

Biersack, A., Jolly, M. \& Macintyre, M. (Eds). (2016). Gender violence and human rights: Seeking justice in Fiji, Papua New Guinea and Vanuatu. Canberra, ACT: ANU Press. doi.org/10.22459/GVHR.12.2016

Boochani, B. (2018). No friend but the mountains: Writing from Manus prison. Sydney, NSW: Pan Macmillan Australia Pty Ltd.

Bryant-Tokalau, J. (2012). Twenty years on: Poverty and hardship in urban Fiji. Bijdragen tot de Taal-, Land-en Volkenkunde, 168(2/3), 195-218.

Burridge, K. (1971). New heaven, new earth: A study of millenarian activities. Oxford, England: Basil Blackwell.

Burton, J. (2018). Are the people of Manda in Middle Fly poor? A development assessment using the Oxford Multidimensional Poverty Index. Contemporary PNG Studies: DWU Research Journal, 28, 85-98.

Choi, H \& Jolly, M. (Eds). (2014). Divine domesticities: Christian paradoxes in Asia and the Pacific. Canberra, ACT: ANU Press. doi.org/10.22459/DD.10.2014 
Coetzee, J. M. (2019, 26 September). Australia's shame. The New York Review of Books. Retrieved from www.nybooks.com/articles/2019/09/26/australiasshamel

Cox, J. (2015). Israeli technicians and the post-colonial racial triangle in Papua New Guinea. Oceania, 85(3), 342-358.

Cox, J. (2018). Fast money schemes: Hope and deception in Papua New Guinea. Bloomington and Indianapolis, IN: Indiana University Press.

Cox, J. \& Macintyre, M. (2014). Christian marriage, money scams and Melanesian social imaginaries. Oceania, 84(2), 138-157.

Cox, J. \& Phillips, G. (2015). Sorcery, Christianity and the decline of medical services in Melanesia. In M. Forsyth \& R. Eves (Eds), Talking it through: Responses to sorcery and witchcraft beliefs and practices in Melanesia (pp. 37-54). Canberra, ACT: ANU Press. doi.org/10.22459/TIT.05.2015

Crenshaw, K. (1989). Demarginalising the intersection of race and sex: A black feminist critique of antidiscrimination doctrine, feminist theory and antiracist politics. University of Chicago Legal Forum, 1989(1), 139-168.

Crocombe, R. (2007). Asia in the Pacific: Replacing the West. Suva, Fiji: IPS Publications.

Dickson-Waiko, A. (2003). The missing rib: Mobilising church women for change in Papua New Guinea. Oceania, 74(1-2), 98-119.

Douglas, B. (1979). Rank, power, authority: A reassessment of traditional leadership in South Pacific societies. The Journal of Pacific History, 14(1), 2-27. doi.org/10.1080/00223347908572362

Douglas, B. (2003). Christianity, tradition and every modernity: Towards an anatomy of women's groupings in Melanesia. Oceania, 64(1), 6-23.

Douglas, B. (2008). Foreign bodies in Oceania. In Douglas, B. \& C. Ballard (Eds), Foreign bodies: Oceania and the science of race 1750-1940 (pp. 3-30). Canberra, ACT: ANU E Press. doi.org/10.22459/FB.11.2008

Errington, F. \& Gewertz, D. (1994). From darkness to light in the George Brown Jubilee: The invention of nontradition and the inscription of a national history in East New Britain. American Ethnologist, 21(1), 104-122.

Errington, F. \& Gewertz, D. (2004). Yalis question: Sugar, culture and history. Chicago, IL: University of Chicago Press.

Filer, C. (1985). What is this thing called brideprice? Mankind, 15(2), 163-183. 
Filer, C. (1997). Compensation, rent and power in Papua New Guinea. In S. Toft (Ed.), Compensation for resource development in Papua New Guinea (pp. 156189). Canberra, ACT: The Australian National University.

Filer, C. \& Le Meur, P. Y. (2017). Large-scale mines and local-level politics: Between New Caledonia and Papua New Guinea. Canberra, ACT: ANU Press. doi.org/ 10.22459/LMLP.10.2017

Filer, C. \& Sekhran, N. (1998). Loggers, donors and resource owners. London, England: International Institute for Environment and Development.

Finney, B. (1973). Big-men and business: Entrepreneurship and economic growth in the New Guinea Highlands. Canberra, ACT: Australian National University Press.

Foster, R. J. (1995). Social reproduction and history in Melanesia: Mortuary ritual, gift exchange and custom in the Tanga Islands. Cambridge, England: Cambridge University Press.

Foster, R. J. (2008). Coca-globalisation: Following soft drinks from New York to New Guinea. New York, NY: Palgrave Macmillan.

Gewertz, D. \& Errington, F. (1999). Emerging class in Papua New Guinea: The telling of difference. Cambridge, England: Cambridge University Press.

Goddard, M. (2005). The unseen city: Anthropological perspectives on Port Moresby, Papua New Guinea. Canberra, ACT: Pandanus Books.

Goddard, M. (2017). A categorical failure: 'Mixed race' in colonial Papua New Guinea. In F. Fozdar \& K. McGavin (Eds), Mixed race identities in Australia, New Zealand and the Pacific Islands (pp. 133-146). New York, NY: Routledge.

Godelier, M. (1986). The making of great men: Male domination and power among the New Guinea Baruya. Cambridge, England: Cambridge University Press.

Godelier, M. \& Strathern, M. (Eds). (1991). Bigmen and greatmen: Personifications of power in Melanesia. New York, NY: Cambridge University Press.

Golub, A. \& Rhee, M. (2013). Traction: The role of executives in localising global mining and petroleum industries in Papua New Guinea. Paideuma, 59, 215-235.

Gregory, C. A. (1982). Gifts and commodities. London, England: Academic Press.

Hall, D., Hirsch, P. \& Li, T. M. (2011). Powers of exclusion: Land dilemmas in Southeast Asia. Singapore: National University of Singapore Press. 
Harvey, D. (2005). A brief history of neoliberalism. Oxford, England: Oxford University Press.

Hau'ofa, E. (1975). Anthropology and Pacific Islanders. Oceania, 45(4), 283-289. doi.org/10.1002/j.1834-4461.1975.tb01871.x

Hildson, A. M., Macintyre, M., Mackie, V. \& Stivens, M. (Eds). (2000). Human rights and gender politics: Perspectives on the Asia Pacific region. London, England: Routledge.

Hobsbawm, E. \& Ranger, T. (Eds). (1983). The invention of tradition. Cambridge, England: Cambridge University Press.

Hukula, F. (2015). Blok laif: An ethnography of a Mosbi settlement (Doctoral thesis). University of St Andrews, Scotland. Retrieved from hdl.handle.net/10023/ 11367

Hukula, F. (2018, 26 September). Melanesian anthropology em nem nating. Society for Cultural Anthropology. Retrieved from culanth.org/fieldsights/melanesiananthropology-em-nem-nating

Hukula, F., Forsyth, M. \& Gibbs, P. (2020). The importance of messaging for COVID-19. What can we learn from messaging against sorcery accusation related violence? National Research Institute Papua New Guinea. Retrieved from pngnri.org/index.php/blog/159-the-importance-of-messaging-for-covid19-what-can-we-learn-from-messaging-against-sorcery-accusation-relatedviolence-2

Jacka, J. (2015). Alchemy in the rain forest: Politics, ecology and resilience in a New Guinea mining area. Durham, NC: Duke University Press.

Johnson, H. \& McGavin, K. (2017). Constructing and interpreting 'mixed race' and 'mixed parentage' in Papua New Guinea. In F. Fozdar \& K. McGavin (Eds), Mixed race identities in Australia, New Zealand and the Pacific Islands. New York, NY: Routledge.

Jolly, M. (1987). The chimera of equality in Melanesia. Mankind, 17(2), 168-183.

Jolly, M. (1992). Specters of inauthenticity. The Contemporary Pacific, 4(1), 49-72.

Jolly, M. (2001). Imagining Oceania: Indigenous and foreign representations of a sea of islands. In D. Yui \& Y. Endo (Eds), Framing the Pacific in the 21st century: Coexistence and friction (pp. 29-48). Tokyo, Japan: Center for Pacific and American Studies, University of Tokyo.

Jolly, M. (2008). Moving masculinities: Memories and bodies across Oceania. The Contemporary Pacific, 20(1), 1-24. 
Jolly, M. (2015). Braed praes in Vanuatu: Both gifts and commodities. Oceania, $85(1), 63-78$.

Jolly, M. (2019). Engendering the anthropocene in Oceania: Fatalism, resilience, resistance. Cultural Studies Review, 25(2), 172-195.

Jolly, M. \& Macintyre, M. (Eds). (1989). Family and gender in the Pacific: Domestic contradictions and the colonial impact. Cambridge, England: Cambridge University Press.

Jolly, M. \& Mosko, M. (1994). Transformations of hierarchy: Structure, history and horizon in the Austronesian world. History and Anthropology, 7(1-4), 1-18.

Jolly, M., Stewart, C. \& Brewer, C. (Eds). (2012). Engendering violence in Papua New Guinea. Canberra, ACT: ANU E Press. doi.org/10.22459/EVPNG. 07.2012

Josephides, L. (1985). The production of inequality: Gender and exchange among the Kewa. London, England: Tavistock.

Josephides, L. (1991). Metaphors, metathemes and the construction of sociality: A critique of the new Melanesian ethnography. Man, 26(1), 145-161.

Kabutaulaka, T. (2015). Representing Melanesia: Ignoble savages and Melanesian alternatives. The Contemporary Pacific, 27(1), 74-145.

Kabutaulaka, T. \& Teaiwa, K. (2019). Climate, coal, kinship and security in AustraliaPacific relations. Retrieved from www.internationalaffairs.org.au/australian outlook/climate-coal-kinship-and-security-in-australia-pacific-relations/

Kapferer, B. (2005). New formations of power, the oligarchic-corporate state and anthropological ideological discourse. Anthropological Theory, 5(3), 285-299.

Keesing, R. (1969). Chiefs in a chiefless society: The ideology of modern Kwaio Politics. Oceania, 38(4), 278-280.

Keesing, R. (1985). Killers, big men and priests on Malaita: Reflections on a Melanesian troika system. Ethnology, 24(4), 237-252. doi.org/10.2307/ 3773736.

Keesing, R. (1992). Custom and confrontation: The Kwaio struggle for cultural autonomy. Chicago, IL: University of Chicago Press.

Keesing, R. \& Jolly, M. (1992). Epilogue. In J. G. Carrier (Ed.), History and tradition in Melanesian anthropology. Berkeley, CA: University of California Press. 
Keesing, R. \& Tonkinson, R. (Eds). (1982). Reinventing traditional culture: The politics of kastom in island Melanesia [Special issue]. Mankind, 13(4).

Kelly, R. (1993). Constructing inequality: The fabrication of a hierarchy of virtue among the Etoro. Ann Arbor, MI: University of Michigan Press.

Kirsch, S. (2014). Mining capitalism: The relationship between corporations and their critics. Oakland, CA: University of California Press.

Klein, N. (2007). The shock doctrine: The rise of disaster capitalism. New York, NY: Metropolitan Books.

Knauft, B. (2019). Good anthropology in dark times: Critical appraisal and ethnographic application. The Australian Journal of Anthropology, 30(1), 3-17.

Koczberski, G., Curry, G. N. \& Anjen, J. (2015). Changing land tenure and informal land markets in the oil palm frontier regions of Papua New Guinea: The challenge for land reform. In G. Curry, G. Koczberski \& J. Connell (Eds), Migration, land and livelihoods: Creating alternative modernities in the Pacific (pp. 67-82). Abingdon, England: Routledge.

Ku, K. H. \& Gibson, T. (2019). Hierarchy and egalitarianism in Austronesia. Anthropological Forum, 29(3), 201-215. doi.org/10.1080/00664677.2019. 1626216

Lahiri-Dutt, K. \& Macintyre, M. (2006). Women miners in developing countries: Pit women and others. Aldershot, England: Ashgate.

Lawrence, P. (1964). Road belong cargo: A study of the cargo movement in the Southern Madang District New Guinea. Melbourne, Vic.: Melbourne University Press.

Lawson, S. (2013). Melanesia: The history and politics of an idea. The Journal of Pacific History, 48(1), 1-22.

Levine, H., B. \& Levine, M. (1979). Urbanisation in Papua New Guinea: A study of ambivalent townsmen. Cambridge, England: Cambridge University Press.

Lindstrom, L. (1993). Cargo cult: Strange stories of desire from Melanesia and beyond. Honolulu, HI: University of Hawai'i Press.

Lindstrom, L. \& Jourdan, C. (2017). Urban Melanesia. Journal de la Société des Océanistes, 144-145(1), 5a-22a.

Macintyre, M. (1983). Warfare and the changing context of Kune on Tubetube. The Journal of Pacific History, 18(1-2), 11-34.

Macintyre, M. (1984). The problem of the semi-alienable pig. Canberra Anthropology, 7(1-2), 109-122. 
Macintyre, M. (1994). Too many chiefs? Leadership in the Massim in the colonial era. History and Anthropology, 7(1-4), 241-262.

Macintyre, M. (1995). Violent bodies and vicious exchanges: Personification and objectification in the Massim. Social Analysis, 37, 29-43.

Macintyre, M. (2011). Modernity, gender and mining: Experiences from Papua New Guinea. In K. Lahiri-Dutt (Ed.), Gendering the field: Towards sustainable livelihoods for mining communities (pp. 21-32). Canberra, ACT: ANU E Press, doi.org/10.22459/GF.03.2011.02

Macintyre, M. (2012). Gender violence in Melanesia and the problem of millennium development goal No. 3. In M. Jolly, C. Stewart \& C. Brewer (Eds), Engendering violence in Papua New Guinea (pp. 239-266). Canberra, ACT: ANU E Press. doi.org/10.22459/EVPNG.07.2012

Macintyre, M. (2017). Flux and change in Melanesian gender relations. In Macintyre, M. \& C. Spark (Eds), Transformations of gender in Melanesia (pp. 1-22). Canberra, ACT: ANU Press. doi.org/10.22459/TGM.02.2017

Macintyre, M. \& Spark, C. (Eds). (2017). Transformations of gender in Melanesia. Acton, ACT: ANU Press. doi.org/10.22459/TGM.02.2017

Martin, K. (2013). The death of the big men and the rise of the big shots: Custom and conflict in East New Britain. New York, NY: Berghahn.

McCormack, M. (2019, 16 August). Pacific islands will survive climate crisis because they 'pick our fruit', Australia's deputy PM says. The Guardian. Retrieved from www.theguardian.com/australia-news/2019/aug/16/pacificislands-will-survive-climate-crisis-because-they-can-pick-our-fruit-australiasdeputy-pm-says

McDonnell, S. (2017). Urban land grabbing by political elites: Exploring the political economy of land and the challenges of regulations. In S. McDonnell, M. G. Allen \& C. Filer (Eds), Kastom, property and ideology: Land transformations in Melanesia (pp. 283-304). Canberra, ACT: ANU Press. doi.org/10.22459/ KPI.03.2017

McDonnell, S., Allen, M. \& Filer, C. (Eds). (2017). Kastom, property and ideology: Land transformations in Melanesia. Canberra, ACT: ANU Press. doi.org/ 10.22459/KPI.03.2017

McDougall, D. (2009). Christianity, relationality and the material limits of individualism: Reflections on Robbins's becoming sinners. The Asia Pacific Journal of Anthropology, 10(1), 1-19. 
McDougall, D. (2015). Customary authority and state withdrawal in Solomon Islands: Resilience or tenacity? The Journal of Pacific History, 50(4), 450-472.

Mead, M. (1956). New lives for old: Cultural transformation - Manus, 1928-1953. New York, NY: William Morrow and Company.

Modjeska, N. (1982). Production and inequality: Perspectives from central New Guinea. In A. Strathern (Ed.), Inequality in New Guinea Highlands societies (pp. 50-108). Cambridge, England: Cambridge University Press.

Morauta, L. \& Ryan, D. (1982). From temporary to permanent townsmen: Migrants from the Malalaua district, Papua New Guinea. Oceania, 53(1), $39-55$.

Morgan, M. (2019). Winds of change: Pacific islands and the shifting balance of power in the Pacific Ocean (SGDIA Working Paper No 10). Retrieved from University of the South Pacific website: apo.org.au/node/262801

Mosko, M. (2015). Unbecoming individuals: The partible character of the Christian person. HAU: Journal of Ethnographic Theory, 5(1), 361-393.

Munro, J. (2017). Gender struggles of educated men in the Papuan highlands. In M. Macintyre \& C. Spark (Eds), Transformations of gender in Melanesia (pp. 45-68). Canberra, ACT: ANU Press. doi.org/10.22459/TGM.02.2017

Murray-Atfield, Y. (2018, 3 October). 'Polio came back': Fears for hundreds of children after first PNG death in 20 years. Australian Broadcasting Corporation. Retrieved from www.abc.net.au/news/2018-10-03/polio-death-recorded-inpng-for-first-time-in-more-than-20-years/10328594

Ortner, S. B. (2016). Dark anthropology and its others: Theory since the eighties. HAU: Journal of Ethnographic Theory, 6(1), 47-73. doi.org/10.14318/hau6.1. 004

Piketty, T. (2014). Capital in the twenty-first century. Cambridge, England: The Belknap Press of Harvard University Press.

Ram, K. \& Jolly, M. (1998). Maternities and modernities. Cambridge, England: Cambridge University Press.

Rawlings, G. (2011). Relative trust: The Vanuatu tax haven and the management of elite family fortunes. In M. Patterson \& Macintyre, M. (Eds), Managing modernity in the Western Pacific (pp. 260-305). St Lucia, Qld: University of Queensland Press. 
Regenvanu, R. (2019, 19 August). Vanuatu will host the next Pacific Islands Forum. We want to know if Australia really wants a seat at the table. The Guardian. Retrieved from www.theguardian.com/world/2019/aug/20/vanuatu-will-hostthe-next-pacific-islands-forum-we-want-to-know-if-australia-really-wants-aseat-at-the-table

Reiter, R. R. (1975). Toward an anthropology of women. New York, NY: Monthly Review Press.

Rio, K. \& Smedal, O. H. (2008). Hierarchy: Persistence and transformation in social formations. New York, NY: Berghahn Books.

Robbins, B. (2017). The beneficiary. Durham, NC: Duke University Press.

Robbins, J. (1994). Equality as value: Ideology in Dumont, Melanesia and the West. Social Analysis, 36, 21-70.

Robbins, J. (2004). Becoming sinners: Christianity and moral torment in a Papua New Guinea society. Berkeley, CA: University of California Press.

Robbins, J. (2013). Beyond the suffering subject: Toward an anthropology of the good. Journal of the Royal Anthropological Institute, 19(3), 447-462. doi.org/ 10.1111/1467-9655.12044

Rooney, M. N. (2017). 'There's nothing better than land': A migrant group's strategies for accessing informal settlement land in Port Moresby. In S. McDonnell, M. G. Allen \& C. Filer (Eds), Kastom, property and ideology: Land transformations in Melanesia (pp. 111-143). Canberra, ACT: ANU Press. doi.org/10.22459/KPI.03.2017

Rooney, M. N. (2018, 26 September). Hotspot: From reciprocity to relationality: Anthropological possibilities. Society for Cultural Anthropology. Retrieved from culanth.org/fieldsights/other

Rooney, M. N. (2020, 11 March). Behrouz Boochani's No Friend but the Mountains: An Oceanian lens. DevPolicyBlog. Retrieved from devpolicy.org/behrouzboochanis-no-friend-but-the-mountain-an-oceanian-lens-20200311/

Rosaldo, M. Z., Lamphere, L. \& Bamberger, J. (1974). Woman, culture and society. Stanford, CA: Stanford University Press.

Sahlins, M. (1963). Poor man, rich man, big-man, chief: Political types in Melanesia and Polynesia. Comparative Studies in Society and History, 5(3), 285-303.

Sahlins, M. (1992). The economics of develop-man in the Pacific. Res: Anthropology and Aesthetics, 21(Spring), 13-25. 
Salyer, J. C. (2018, December). Old savage, new savage: The denial of human dignity in the age of human rights. Paper presented at the European Society for Oceanists, Cambridge, England.

Scott, M. W. (2007). Neither 'new Melanesian history' nor 'new Melanesian ethnography': Recovering emplaced matrilineages in Southeast Solomon Islands. Oceania, 77(3), 337-354. doi.org/10.1002/j.1834-4461.2007. tb00020.x

Sharp, T., Cox, J. Spark, C., Lusby, S. \& Rooney, M. (2015). The formal, the informal and the precarious: Making a living in urban Papua New Guinea (SSGM Discussion Paper 2015/2). Canberra, ACT: The Australian National University.

Shaxson, N. (2011). Treasure islands: Tax havens and the men who stole the world. London, England: Palgrave Macmillan.

Siegel, J. (1985). Origins of Pacific Islands labourers in Fiji. Journal of Pacific History, 20(1), 42-54.

Sillitoe, P. (1979). Give and take: Exchange in Wola society. Canberra, ACT: Australian National University Press.

Smith, G. (2013). Nupela masta? Local and expatriate labour in a Chinese-run nickel mine in Papua New Guinea. Asia Studies Review, 37(2), 178-195.

Spark, C. (2017). Getting comfortable: Gender, class and belonging in the 'new' Port Moresby. Journal of the Société des Océanistes, 144-145(1), 147-158.

Spark, C. (2019). At home in the city: Educated women, housing and belonging in Port Moresby. In S. Pinto et al. (Eds), Interdisciplinary unsettlings of place and space: Conversations, investigations and research (pp. 183-195). Singapore: Springer.

Spark, C. (2020). 'Two different worlds': Papua New Guinean women working in development in Port Moresby. Asia Pacific Viewpoint. doi.org/10.1111/ apv. 12271

Spark, C., Cox, J. \& Corbett, J. (2019). Gender, political representation and symbolic capital: How some women politicians succeed. Third World Quarterly, 40(7), 1227-1245.

Stead, V. (2020, 24 March). Australia's food supply relies on migrant workers who are facing coronavirus limbo. The Guardian. Retrieved from www.theguardian. $\mathrm{com} /$ world/commentisfree $/ 2020 / \mathrm{mar} / 24 /$ australias-food-supply-relies-onmigrant-workers-who-are-facing-coronavirus-limbo 
Stead, V. \& Altman, J. (Eds). (2019). Labour lines and colonial power: Indigenous and Pacific Islander labour mobility in Australia. Canberra, ACT: ANU Press. doi.org/10.22459/LLCP.2019

Strathern, A. (1971). The rope of Moka: Big-men and ceremonial exchange in Mount Hagen, New Guinea. Cambridge, England: Cambridge University Press.

Strathern, A. (1982). Inequality in New Guinea Highlands societies. Cambridge, England: Cambridge University Press.

Strathern, M. (1975). No money on our skins: Hagen migrants in Port Moresby. Port Moresby, Papua New Guinea: The Australian National University.

Strathern, M. (1987). Dealing with inequality: Analysing gender relations in Melanesia and beyond. Cambridge, England: Cambridge University Press.

Strathern, M. (1988). The gender of the gift. Berkeley, CA: University of California Press.

Taylor, J. (2008a). The social life of rights: 'Gender antagonism', modernity and raets in Vanuatu. The Australian Journal of Anthropology, 19(2), 165-178.

Taylor, J. (2008b). Changing Pacific masculinities: The 'problem' of men. The Australian Journal of Anthropology, 19(2), 125-135.

Teaiwa, K. (2019). No distant future: Climate change as an existential threat. Australian Foreign Affairs, 6, 51-70.

Thomas, N. (1989). The force of ethnology: Origins and significance of the Melanesia/Polynesia division. Current Anthropology, 30(1), 27-41.

Tomlinson, M. \& McDougall, D. (2013). Christian politics in Oceania. New York, NY: Berghahn.

Trnka, S. (2008). State of suffering political violence and community survival in Fiji. Ithaca, NY: Cornell University Press.

United Nations Development Programme. (2018). United Nations Development Programme annual report 2018. Retrieved from annualreport.undp.org/

Wardlow, H. (2006). Wayward women: Sexuality and agency in a New Guinea society. Berkeley, CA: University of California Press.

Wardlow, H. (2018, December). Thinking through intersectionality and gender inequality in Papua New Guinea. Paper presented at the European Society for Oceanists, Cambridge, England. 
West, P. (2016). Dispossession and the environment: Rhetoric and inequality in Papua New Guinea. La Vergne, TN: Columbia University Press.

West, P. (2018, December). Dispossession and disappearance in the post sovereign Pacific: The regional resettlement agreement between Australia and Papua New Guinea, an ethnography of loss. Paper presented at the European Society for Oceanists, Cambridge, England.

White, G. M. (1991). Identity through history: Living stories in a Solomon Islands society. Cambridge, England: Cambridge University Press.

White, G. M. (1992). The discourse of chiefs: Notes on a Melanesian society. The Contemporary Pacific, 4(1), 73-108.

White, G., M. \& Lindstrom, L. (Eds). (1997). Chiefs today: Traditional Pacific leadership and the postcolonial state. Stanford, CA: Stanford University Press.

Wilkinson, R. G. \& Pickett, K. (2009). The spirit level: Why more equal societies almost always do better. London, England: Allen Lane.

Winter, C. (2017). Lingering legacies of German colonialism: The 'mixed race' identities in Oceania. In F. Fozdar \& K. McGavin, Mixed race identities in Australia, New Zealand and the Pacific Islands (pp. 147-161). New York, NY: Routledge.

Wood, T. (2020, 30 March). What will COVID-19 mean for the Pacific: A problem in four parts. DevPolicyBlog. Retrieved from devpolicy.org/whatwill-covid-19-mean-for-the-pacific-a-problem-in-four-parts-20200330/

World Bank. (2018). Poverty and shared prosperity 2018: Piecing together the poverty puzzle. Washington, DC: World Bank.

Zimmer-Tamakoshi, L. (1993). Nationalism and sexuality in Papua New Guinea. Pacific Studies, 16(4), 20-48.

Zimmer-Tamakoshi, L. (1997). The last big man: Development and men's discontents in the Papua New Guinea Highlands. Oceania, 68(2), 107-122.

Zimmer-Tamakoshi, L. (1998). Women in town: Housewives, homemakers and household managers. In L. Zimmer-Tamakoshi (Ed.), Modern Papua New Guinea (pp. 195-210). Kirksville, MO: Thomas Jefferson University Press. 
This text is taken from Unequal Lives: Gender, Race and Class in the Western Pacific, edited by Nicholas A. Bainton, Debra McDougall, Kalissa Alexeyeff and John Cox, published 2021 by ANU Press, The Australian National University, Canberra, Australia.

doi.org/10.22459/UE.2020.01 